\title{
ESTUDIOS LITERARIOS SOBRE LA CIUDAD EN LA REVISTA CHILENA DE LITERATURA. 1970-2000
}

\author{
Cristián Cisternas Ampuero \\ Universidad de Chile \\ Santiago de Chile, Chile \\ ccistern@uchile.cl
}

En reconocimiento a mis maestros en los estudios literarios.

CCA

\section{RESUMEN / ABSTRACT}

Este ensayo revisa un corpus de artículos publicados en la Revista Chilena de Literatura en el periodo de 1970-2000. Estos artículos se centran en el análisis de obras poéticas y narrativas que tienen en común la representación de la ciudad y lo urbano. El ensayo muestra el cambio diacrónico en las perspectivas de análisis, desde una visión inmanente de la obra literaria hasta su inserción en un panorama cultural heterogéneo. Característica de este periodo de fin de siglo es la aproximación a la literatura y a la experiencia del habitar urbano desde teorías de género, de crítica cultural y análisis post-estructural. Se concluye que el objeto de representación, la ciudad, es un punto focal de debate político, estético y de género en torno al concepto de modernidad en Latinoamérica.

Palabras clave: Revista Chilena de Literatura, representación de la ciudad, período 19702000, análisis literario.

\section{Literary STUDIES ABOUT THE CITY IN THE REVISTACHILENA DE LITERATURA.}

1970-2000

This essay reviews a corpus of articles published in Revista Chilena de Literatura during the 1970-2000 period. These articles focus on the analysis of poetic and narrative works that share in common the representation of the city and the urban space. The essay shows a diachronic change in analysis perspectives that shift from an immanent vision of the literary work to its insertion in a heterogeneous cultural panorama. By the end of the century, a salient characteristic is the approach to literature and the experience of urban interaction from 
gender theories, cultural criticism, and post-structural analyses. As a conclusion, the object of representation, the city, appears as a focal point of political, aesthetic and gender-oriented debate around the concept of Modernity in Latin American societies.

KEYWORDS: Revista Chilena de Literatura, representation of cities, 1970-2000 historical period, literary analisis.

Recepción: 13/05/2019

Aprobación: 02/08/2019

\section{INTRODUCCIÓN}

El tópico de comparación entre civilización y naturaleza, o entre vida urbana y vida rústica, es de larga data en Occidente ${ }^{1}$. A partir del siglo XIX, en el contexto de la industrialización y crecimiento de las sociedades occidentales, el escenario urbano se refleja en géneros tradicionales como poesía y teatro, en novelas históricas y sentimentales y en cuentos o relatos. También repercute en géneros nuevos, propios de la vida metropolitana, como la crónica de costumbres, el folletín y los diarios íntimos. Incluso, los géneros tradicionales adaptan las técnicas y formas distintivas de la socialización moderna a un tipo de lector, inserto en espacios públicos y privados, que demanda y recibe la representación de su propia cotidianidad: surge la literatura de ciudades.

Los estudios teóricos centrados en la representación literaria de la ciudad han ido evolucionando, sin duda, a partir de modificaciones en las teorías literarias al uso, coyunturas históricas y cambios de paradigmas sociales y culturales ${ }^{2}$. En el caso de la literatura y los estudios literarios chilenos, la academia ha prestado atención, desde la segunda mitad del siglo XX, al impacto de la modernización urbana en las temáticas y técnicas de la narrativa, la poesía y la dramaturgia. Como siempre, han sido los creadores quienes se han adelantado a los críticos, pero la acogida de los estudiosos de la literatura ha sido fructífera.

El objetivo de este trabajo es analizar un corpus de ensayos publicados entre los años 1970 y 2000 en la Revista Chilena de Literatura del Departamento de

\footnotetext{
Para un desarrollo de este tópico, ver: Lefebvre, Henri, El derecho a la ciudad. Capítulo: "Ciudad y campo", 1969.

Un enfoque de las perspectivas actuales sobre el vínculo entre cultura y ciudad se encuentra en Setha M. Low, 1996.
} 
Literatura de la Universidad de Chile. Este espacio de producción y difusión de conocimiento sobre las Humanidades ha alcanzado, progresivamente, un nivel internacional, contando con la presencia de reconocidos especialistas que publican en sus páginas. El corpus escogido abarca desde el primer número de la Revista Chilena de Literatura (1970) hasta el año 2000, momento histórico que marca una inflexión profunda en el examen crítico de los cánones literarios vigentes en la crítica y en la enseñanza de la literatura en niveles superiores. A manera de hipótesis, planteo que se observa nítidamente un cambio en el enfoque del fenómeno literario y de la forma cómo la literatura se hace cargo de la realidad. Por ejemplo, desde el enfoque estilístico e inmanentista de los años setenta, de Carlos Morand, hasta el análisis con perspectiva de género de Lucía Guerra Cunningham, se percibe una ampliación en términos interpretativos de la escritura desde la ciudad y sobre la ciudad. Junto con ser el trasunto estilístico de una intuición genial, como en el caso de Arthur Rimbaud, la ciudad influye en la creación de nuevos circuitos comunicativos, y permite abordar problemáticas sociales y estéticas con el trabajo formal sobre el lenguaje. Antiguos tópicos literarios son parodiados y desmitificados; la imagen del artista mismo, como paseante, lector y productor de discursos, desde localizaciones ficticias o temporalidades dislocadas, aparece como lugar dinámico y en permanente conflicto con el cambio cultural. Especialmente, la coyuntura histórica que golpea al país en 1973 genera notorios cambios en la perspectiva de análisis, en la selección del material y en las herramientas teóricas usadas para leer la producción literaria en Chile y otros países.

Más específicamente, observamos tres etapas distintas en el enfoque y análisis de la creación literaria en relación con la ciudad. La primera, entre 1970 y 1977, oscila entre el análisis sociocultural y el enfoque estilístico inmanentista. Entre 1985 y 1987, se reconoce explícitamente la existencia de la temática urbana y su impacto concreto en la poesía chilena contemporánea, que desemboca en la aparición de la antipoesía. Los dos artículos de Soledad Bianchi, separados por doce años de trayectoria $(1987,1999)$ reconocen una herramienta básica de análisis, según nuestro parecer, en el trabajo hermenéutico: la diferencia entre tematización de la ciudad y su representación según estrategias de enunciación experimentales. Los estudios de Gloria Favi (1992, 1995) centrados en Enrique Lihn, poeta urbano por excelencia (así lo reconoce Federico Schopf), tanto en su lírica como en su crónica, introducen 
herramientas de análisis como la teoría de los actos de habla ${ }^{3}$. Al mismo tiempo, en los textos de Favi se reconoce la importancia de la lectura crítica desarrollada por los artistas audiovisuales durante la dictadura chilena y el retorno a la democracia. Aparece la representación de la ciudad en relación con la parodización de tópicos previos (el panegírico de la crónica de conquista da paso a la ciudad como espacio infernal, laberíntico y enfermizo), a la vez que se instala el debate (pesimista, hay que reconocerlo) sobre el impacto del modelo económico y social del neoliberalismo. Éste repercute en la planificación de los espacios urbanos tanto como en la redefinición de lo público, lo privado y lo subjetivo del ser domiciliado. En este sentido, el trabajo de Bianchi (1993) resulta esclarecedor en la medida en que reflexiona sobre la noción de paisaje urbano ${ }^{4}$ y establece, como característica de la producción literaria del período, la aparición de géneros ambiguos y temáticas marginales que aspiran a copar el establecimiento editorial y académico tanto como la escena artística misma.

Finalmente, los textos de Epple y Lucía Guerra instalan el análisis en el contexto del debate sobre la desmodernización, junto con los movimientos de liberación homosexual y la teoría literaria feminista. Ambos enfoques destacan la representación de la ciudad y sus textualizaciones en un momento de cambio histórico: traspaso de milenio; avance del capitalismo en Latinoamérica; cambio de paradigmas teóricos. Se anuncian, o se intuyen, las relecturas de las identidades nacionales, genéricas y sociales, que darán paso a los debates sobre posnacionalismo, crítica cultural y, finalmente, sobre posmodernidad. Como veremos, ello enriquece, a la vez que revalida, la representación y textualización de la urbanidad en una larga tradición literaria que conecta a Latinoamérica con Occidente, con las premodernidades originarias y, finalmente, con los tópicos heredados de la Antigüedad.

3 Searle, John, 1969.

4 Es decir, espacio textual que corresponde a la lectura semiótica y "situada" de la ciudad y sus signos. 


\section{ANTONIO SKÁRMETA: LA CRÍTICA DE LA CIUDAD Y LA TOMA DE CONCIENCIA FRENTE AL CONFLICTO SOCIAL (1970)}

Antonio Skármeta (1940), reconocido escritor y ensayista chileno, escoge para su análisis dos obras importantes dentro de la escena dramática del teatro chileno del siglo XX: Pueblecito (1918), de Armando Moock, y La canción rota (1933), de Antonio Acevedo Hernández. Si bien privilegia el análisis de la primera, inserta ambas obras en el tópico tradicional de contrapunto entre vida rural frente a vida urbana, una temática recurrente en el teatro y la narrativa nacional desde el siglo XIX (Alberto Blest Gana, "Jotabeche" y Daniel Barros Grez, por ejemplo). En estos escritores (a diferencia de Moock y Luco Cruchaga) la oposición se resuelve con el triunfo, o defensa, de los méritos rurales por sobre los ciudadanos, es decir, al interior de una ideología integrada. Por el contrario, analizando la estructura dramática de Pueblecito y La viuda de Apablaza, Skármeta señala que:

En cada una de estas piezas hay un personaje específico, de vuelta de la ciudad, que obra sobre el espacio rural afectando de alguna manera el habitus vivendi de los pobladores locales [...] causándoles un movimiento de conciencia que los ilumina con respecto a valores más hondos y universales que los que celebra o denigra el tópico: pasión, amor, justicia (Skármeta 32).

Para Skármeta, el conflicto dramático se despliega cuando el personaje citadino, Marta, poseedor de una experiencia desencantada de la vida urbana, compara esta visión crítica con la imagen mitificada de la civilización que los personajes provincianos tienen. En la interacción dramática (sentimental, costumbrista y política) surge la posibilidad de entender la oposición pueblo/ ciudad en términos más generales y, por lo mismo, más auténticos: a través de la toma de conciencia de clase, necesariamente conflictiva, de personajes como Salvador, en La canción rota, de Acevedo Hernández. Por otra parte, falso es el desencanto de la mujer santiaguina, como falsa es la construcción romántica de las provincianas (Teresa y Marcela). Igualmente ingenua (y por ello, también desprovista de valor argumentativo) es la defensa de una vida rural en armonía con la naturaleza, sostenida por Marta: esquema simplista que se origina en el tópico mítico de la aetas aurea ${ }^{5}$. Argumenta Skármeta:

\footnotetext{
"An imagined period in early human history when human beings lived a life of ease, far from toil and sin. The most important text is Hesiod, [...] which talks of a 'golden
} 
[...El personaje femenino de Moock, Marta] al abultar los méritos del orden natural, minimiza los valores vitales, casi decidiendo, verbalmente, por un mundo ahistórico. Esta es su resignación”.

MARTA: Felices los que viven con la vista agachada hacia la tierra, porque van deleitando sus ojos en el paisaje, porque un día han de llegar, sin saber que van a la línea donde se pierde el horizonte, y no sabrán que han llegado (Moock, cit. en Skármeta 35).

De modo tal que la oposición valórica misma, implícita en el tópico, resulta ser históricamente inadecuada e insuficiente para superar los conflictos personales (individualistas) de los personajes: el tópico mismo es enajenante. Dice el articulista: "Por lo tanto, ni la ciudad es el lugar plenamente despreciable, ni el pueblo la solución. Lo que hay por debajo de ambas manifestaciones verbales, el drama mismo, desborda en Pueblecito, de Armando Moock, la habitual polarización del tópico (Skármeta 37).

Es oportuno señalar que, dado el contexto histórico e intelectual en que se escribe este artículo (1970), el análisis de Skármeta, si bien sensible a los valores estéticos de la escritura de Moock y Luco Cruchaga, privilegia el análisis del conflicto ideológico al interior de los textos. Y ello por una razón bastante pertinente; las propias obras, al escribirse desde la tensión entre las corrientes romántica, costumbrista y realista de la época, estaban produciendo discursos complejos de leer y de representar, abiertos a una revisión de las tradiciones literarias vigentes. Más aún, en la lectura comprometida de Skármeta, se argumenta que:

El hecho de que haya que buscar la verdad viva de la oposición ciudad-aldea, más que en los enunciados de los personajes en el sistema de relaciones dramáticas que entablan entre ellos, señala que en estas obras la oposición en que la ciudad es desmedrada, es sólo un aspecto muy exterior de la pieza, corroído por la propia actividad de los caracteres foráneos, con la secuela de afectos que entran a modificar no la ruralidad (hay que concederle mucho más

genos', i.e. species or generation, as the first in a series: reference to a golden age occurs first in Latin (aurea saecula, aureaaetas). Oxford Classical Dictionary, enlínea: https://oxfordre.com/ classics/view/10.1093/acrefore/9780199381135.001.0001/acrefore-9780199381135-e-2862. Consultado en mayo de 2019. 
que costumbrismo a estas obras) sino a provocar una conmoción en los personajes [...] (Skármeta 32, destacado mío).

Más que en el discurso directo, o en el trasunto lingüístico de la subjetividad de los personajes realistas, han de observarse las relaciones estructurales entre los personajes, la estructura dramática misma y el efecto final (resolución de conflictos, catástrofe, happy end). Esto conlleva el efecto catártico de la conmoción que, obviamente debería traspasarse de manera efectiva a los espectadores. Y esta conmoción no es sino la revelación de la verdad viva, es decir, ideológicamente revelada, que podría permanecer oculta en una recepción más integrada o menos comprometida de las obras. Si esta "verdad viva" es más auténtica por ser parte de una visión política de la sociedad, o por poseer una cualidad filosófica específica, es algo que no se discutirá aquí.

La visibilización de la verdad viva, el verdadero conflicto y sus alcances, aparecen encarnados en personajes que tienen la capacidad de levantar un discurso crítico y de movilizar las ideas en el espacio ideológico de la realidad representada. En el caso de La canción rota, más importante que la arista sentimental de la fábula es el punto de vista introducido por personajes como Salvador. Según Skármeta:

El elogio del paisaje natural que dice Salvador es mucho más discreto que el de Marta en Pueblecito. Ve el campo como la posible fuerza de recuperación para su salud maltrecha [...] En cambio, el denuesto de la ciudad es enfático. No deja zona sin cubrir en la amarga descripción (Skármeta 39):

Hay personas-leones y personas-sabandijas que son peores que las fieras, porque saben sonreír y acariciar, fábricas cerradas que jamás dejan de sonar con un rumor que atonta y asesina, los pobres que son los únicos que trabajan, son miserables, las enfermedades andan sueltas y la crueldad de los poderosos es desbordada, y cuando se pide algo de comer para no morirse de hambre castiga la justicia (Acevedo Hernández, cit. en Skármeta 39).

Salvador, nieto enfermo y culto que vuelve "desencantado de la ciudad" procurando revitalizarse en todo sentido en el campo" (Skármeta 38) es el personaje ${ }^{6}$ que introduce el conflicto sociopolítico en el texto costumbrista:

6 La crítica del personaje Salvador hacia el habitar urbano de principios de siglo XX contiene, prácticamente, todos los tópicos negativos que la intelectualidad, tanto de América 
Irrumpe con una catequización política el orden "natural" y lleva a los pobladores a la rebelión. Esta toma de conciencia viene apadrinada por su experiencia en la ciudad. Allí el juego social es superado en sus términos de oposición de ricos y pobres. La conciencia de los poderes del proletariado cuando se une, establece una dinámica oposición política: explotadores y explotados (Skármeta 39).

El análisis de Skármeta enfatiza la conciencia falsa de los personajes (expresada en lo que el ensayista llama plano verbal) frente al despertar político que promueve el joven personaje:

Aparte de la aclaración de los términos sociales en pugna según el esquema marxista, Salvador amplía el proceso de concientización, que no es sino una retirada del mundo vivido hasta entonces para entender la situación como limitada y susceptible de cambio, hasta revelar un nuevo sentido de la acción de los carabineros, los sacerdotes y los jueces (Skármeta 40).

Observemos que la lectura de Skármeta acierta al proponer una propuesta desmitificadora en el tratamiento del tópico literario por parte del dramaturgo, descubriendo una dimensión ideológica posible en la obra que, a la luz del análisis sociológico, vigente en la década de los setenta, señala el camino de la toma de conciencia de los conflictos de clase que mueven a la sociedad moderna (en particular, la sociedad agraria y metropolitana chilena), y que se propone como "proceso de autentización". Que no es otra cosa que la representación de una referencialidad histórica y, por lo tanto, conflictiva, sin recurrir a "esquemas simplificadores", como podrían serlo el final feliz o el predominio del color local costumbrista por sobre el realismo social.

\section{CARLOS MORAND: LA ILUMINACIÓN INMANENTE DE LAS CIUDADES (1977)}

Pionero autor del estudio Visión de Santiago en la novela chilena (1988), Carlos Morand (1936) realiza una lectura paradigmática de intuición estilística en

del Norte como de Europa, atribuyen a la vida en las metrópolis: "Envidia, ambiciones, codicia, la. cultura como degeneración de la civilización, lujuria, organismos debilitados, lucha desesperada por el mendrugo de pan, neurosis" (Skármeta 35). 
su artículo sobre Illuminations (1886) de Arthur Rimbaud. En este ensayo, si bien se establece el correlato referencial con el autor (en este caso, Rimbaud viajero y conocedor de ciudades), se enfatiza el proceso de transformación y recreación de la experiencia urbana en escritura vanguardista, que devuelve la autonomía del texto literario a su dimensión profética y hermenéutica sobre el habitar urbano y la condición esencial del sujeto moderno. Como temática, aparecen las nociones de desmesura, tumulto y movimiento, expresiones de la energía cinética impulsada por la técnica. A esto se agrega la aceleración de la percepción de la experiencia, representada por la imagen del torbellino social. Al inicio de su artículo, el profesor Morand afirma:

La ciudad es uno de los temas que se repite en los poemas que componen el volumen Les Illuminations, de Rimbaud. Observada en general, la ciudad rimbaldiana [sic] se dibuja casi siempre como una entidad irreal, imaginada, incompatible con la vida ordinaria y separada del mundo conocido. Sin embargo, si observamos bien algunos poemas en que la ciudad aparece como tema central, podemos advertir que tales espacios imposibles nacen de una visión desmesurada que, no obstante, tiene su correspondencia con el mundo urbano contemporáneo al poeta, y también son una visión, diríase profética, de las ciudades futuras. El genio de la "voyance" rimbaldiana adquiere su máxima potencia poética en la concepción de estos alucinantes mundos urbanos (Morand 109).

Resulta interesante la estrategia interpretativa, simple pero eficiente, que propone el profesor Morand, al escoger un conjunto de poemas de Illuminations, cuya temática común es la ciudad. Estos son: "Ouvriers" (XIII); "Les Ponts" (XIV); "Ville" (XV); "Ornieres" (XVI); "Villes I" (XVII); "Villes II" (XIX); "Métropolitain" (XXVIII), y "Promontoire" (XXX).

Partiendo del carácter abierto de estos textos vanguardistas, el autor rearticula el orden escritural del texto y propone una línea de sentido que va desde la representación anecdótica de la ciudad hasta su transubstanciación escritural en visión surrealista del orbe. Desde una óptica más realista y testimonial -mimética, dentro de las licencias poéticas-se llega a la imagen simbolista que Morand llama la ciudad total, supra-ciudad o ciudad-síntesis.

En "Ouvriers", la tradicional representación naturalista de una ciudad, agostada por la pobreza, da paso a la elaboración poética de un Yo lírico que subtiende el proceso creativo al recuerdo de infancia que introduce la imagen pastoral suburbana. Esta imagen, contradictoria en sí, pero coherente con 
el objetivo de salvar al campo frente a la ciudad, es un ideologema que está presente en la mayoría de los intelectuales del siglo XIX en Europa y América. Además, la introducción del circo, espectáculo asociado con el tópico del mundo como teatro, es destacada acertadamente por el profesor Morand. En el poema "Ville I", el autor enfatiza la aparición de la yuxtaposición de imágenes, a la manera de montaje, junto con la mezcla de planos subjetivoobjetivo, ahondando en el tópico de la ciudad oscura (la ciudad carbón de Lewis Mumford) ${ }^{7}$, enfocada por el punto de vista del Yo testigo que mira a través de una ventana (encuadre, a la vez, romántico y modernista). El ciudadano se define como efímero y "no demasiado descontento" habitante de la modernidad.

A partir de Villes I, el ensayista deduce las principales características de la ciudad moderna, abordada por Rimbaud en sus poemas: 1) El gigantismo, la desmesura (idea que volvemos a encontrar en la teoría de lo real maravilloso de Alejo Carpentier ${ }^{8}$; 2) El ruido ensordecedor, y, como sinestesia, la inarmonía y la agresión del ambiente al mundo retirado y silencioso del artista romántico; 3 ) El movimiento y circulación incesantes, a la manera de un torrente sanguíneo (la metáfora se la debemos a Harvey) $)^{9}$ y 4) Heterogeneidad, pluralidad, incoherencia y caos como principios organizadores del mundo, reproducidos en el sueño y en la estructura del texto. Mediante el procedimiento estilístico del montaje, se caracteriza al poema como "un gran cuadro compuesto de fragmentos y detalles tomados de otros cuadros en un montaje de imágenes sucesivas" (Morand 113). El ruido y el movimiento se asocian con la imagen más evidente del maquinismo avanzado; la heterogeneidad espacial y temporal es atributo de una nueva forma de sincronía, imposible de abarcar con la cronotopía del tiempo lento de la era premoderna.

Por otra parte, la fragmentación de la enunciación en "Villes I" introduce el cronotopo de la condensación de pasado y presente; mito y modernidad; visión y referencia; paisaje exótico y paisaje prosaico; Oriente y Occidente. El lector ideal de Illuminations se enfrenta a una composición instantánea de una heterogeneidad imposible de representar, salvo con la aproximación

\author{
Mumford, Lewis, The Culture of Cities(1938). \\ Véase Prólogo a El reino de este mundo, 1996 (1949). \\ Harvey, William, Exercitatio Anatomica de Motu Cordis et Sanguinis in Animalibus
}

(1628). 
visual del cuadro impresionista, devenido en escena expresionista o surrealista. Dice el autor del artículo:

Somos llevados geográfica y mitológicamente de América a Bagdad, de Rolando a Diana y Venus. Toda la historia, la mítica y la real, está evocada en el poema, pero siempre en una relación, a veces tenue, con las ciudades, la creación máxima del hombre. En medio de estos extremos está el enunciador, quien desciende del sueño a la ciudad subjetiva en el acto de enunciación. Esta tiene la forma de una visión y la lógica de un sueño (Morand 113-114).

En "Villes II", se intensifica la desmesura de la ciudad y, por lo tanto, su carácter irrepresentable. A la vez sublime y aterradora, la ciudad aparece como lo que no puede decirse, salvo reconociendo el fracaso mismo en la enunciación.

Ante tal despliegue de edificaciones colosales, estructuras levantadas en diferentes planos y niveles, profundidades insoslayables, perspectivas caprichosas, sólo cabe el asombro y la renuncia a entender. "Pour l'étranger de notre temps la reconnaissance est impossible" (Rimbaud cit. en Morand 115).

Lo sublime y lo inefable forman parte de lo siniestro urbano (o lo gótico urbano) que escritores como Ernesto Sábato (Sobre héroes y tumbas (1961), y Ricardo Piglia (La ciudad ausente, 1992) desarrollan en Latinoamérica.

En su análisis de Illuminations, el profesor Morand rastrea las nociones de extranjeridad y nomadismo del sujeto cívico, poetizadas por Constantino Kavafis y teorizadas por Oswald Spengler en La decadencia de Occidente (1923). La noción de barbarie moderna, que introduce Rimbaud en "Villes II", evoca el momento de la desintegración urbana y del escape del ciudadano, convertido ahora en sujeto extranjero, hacia el extrarradio de la metrópolis. Solo la estética del collage permite un principio de representación de la ciudad; "bloques que se yuxtaponen en una serie lineal, sin repetirse jamás" componen un cuadro que hace presente en el texto un "mundo urbano que es una Ciudad-Suma, un Arquetipo" (Morand 116). La pregunta que surge aquí es si este arquetipo corresponde a una exageración retórica del tópico de lo sublime-moderno, o si es una señalización hacia la reescritura de la heterogeneidad etológica de la ciudad por medio de recursos escriturales ya agotados. Rimbaud, romántico, tensiona el lenguaje estético hasta el límite para sugerir la imposibilidad de la retórica visual y del collage prevanguardista para 
expresar la ansiedad generada por el cronotopo urbano. Sorpresivamente, la fuga del artista hacia el suburbio, en vez de conducirlo al espacio del lumpenproletariado, lo conduce donde los "gentilhombres salvajes", habitantes del suburbio burgués. Estos viven leyendo el periódico, junto a una naturaleza recuperada para el sentimiento pastoral que se niega a desaparecer en el contexto metropolitano.

Por otro lado, en el análisis de "Promontoire", Morand observa la aparición de una ciudad-síntesis de metrópolis antiguas y modernas como Nueva York, Scarborough, Cartago y Venecia, arquetipos de diferentes momentos de la urbanización en Occidente: ciudad colonizadora, imperial, industrial; ciudades talasocráticas y continentales. La imagen topológica que surge aquí es del hotel en que se aloja el poeta, lugar provisional y cosmopolita que reúne todas las razas y costumbres, conectadas por ferrocarriles en perpetuo movimiento ${ }^{10}$.

En los siguientes poemas, se llega a la última etapa en los procesos de representación de lo urbano a que recurre Rimbaud. En los poemas "Les Ponts" y "Metropolitain", la ciudad aparece representada metonímicamente por los puentes, estructuras cargadas de significado (Martin Heidegger se refiere filosóficamente al puente en su ensayo "Construir, habitar, pensar") ${ }^{11}$. La desmesura de los puentes empequeñece y dispersa a los ciudadanos. El paisaje construido con palabras es denegado por la afirmación de que el ethos presentado corresponde a una comedia. Es decir, se actualiza el viejo tópico de la vida social como teatro ("teathrum mundi"): "Ese paisaje de puentes es un espejismo, una ficción, un escenario teatral, una entidad ilusoria que ha venido a ejercer un papel efímero, o simplemente un sueño que se disuelve al ser tocado por la luz de la vigilia" (Morand 117). La ficción romántica introduce el recurso ambiguo de la ensoñación y el sueño para referir las visiones que el espacio urbano genera en el poeta. En "Ville II", el proceso de desintegración de la representación lineal de la ciudad conlleva imágenes oníricas mezcladas con apuntes realistas, que se refieren a una ciudad destruida por la guerra. ucrónico (en su momento) como un espacio interconectado por el poder de los trenes y la tecnología de la era del vapor (steam). De aquí proviene la estética visual y literaria del Steampunk, propia de la posmodernidad europea.

11 Heidegger, Martin, "Bauen, Wohnen, Denken” (1951). 
Mérito del profesor Morand, en su análisis de Les Illuminations, es demostrar los procedimientos estilísticos y temáticos, así como los recursos visuales usados por Rimbaud para hacerse cargo del escenario urbano global en tanto y en cuanto objeto de representación poética que tensiona los medios de representación del simbolismo, del realismo y el impresionismo literarios. Dicho de otra manera, Rimbaud, como Baudelaire, introduce a la ciudad como espacio estético de la modernidad, poetizando (básicamente, a través de la ambigüedad de la imagen y del montaje visionario) las contradicciones que el tópico tradicional no puede resolver sin pasar al nivel siguiente, el de la surrealidad.

\section{FEDERICO SCHOPF: LA CIUDAD EN LA POESÍA CHILENA CONTEMPORÁNEA (1985)}

Federico Schopf (1940), poeta y académico chileno, ha hecho de la poesía chilena contemporánea su área de especialización. Su artículo propone que se podría escribir una historia de la ciudad en la poesía chilena, reconociendo la importancia, tanto de la experiencia urbana en las generaciones de escritores, como el estímulo estético y social que ésta genera en los poetas. Esta idea, propedéutica, sugiere que el desarrollo de la poesía chilena contemporánea es esencialmente urbano, en la medida en que enfrenta y resuelve asuntos estéticos, políticos y, en definitiva, cívicos, que alcanzan hasta nuestros días.

Schopf inicia su ensayo diferenciando, como lo hará Soledad Bianchi, entre contenido representado y realidad activa en la producción poética. La ciudad aparece como índice de la modernidad desde la experiencia de Rubén Darío en Chile y Buenos Aires (Autobiografía, 1918), modernidad que exalta al poeta a concebir iluminaciones como las de Rimbaud, pero que también lo induce a descubrir realidades sociales de pobreza e inequidad. En este punto, Schopf hace una observación programática: "Las verdaderas consecuencias directas e indirectas del modernismo se manifiestan algo más tarde, en la obra de poetas como Manuel Magallanes Moure, Gabriela Mistral o Carlos Pezoa Véliz. La obra de este último debería estudiarse en el interior del contexto urbano, en el barrio popular, el desclasamiento, la crítica social, el conventillo" (Schopf 37). Indudablemente, la obra de escritores como Mauricio Redolés, Tomás Harris, Eugenia Brito y Rodrigo Grez confirma esta observación. 
El análisis de Schopf se centra en poetas de provincia, como Pablo Neruda y Nicanor Parra, y en sujetos urbanos como Enrique Lihn. En relación con Neruda, el autor del ensayo rastrea la importancia de la experiencia urbana en su poesía temprana, especialmente la oposición entre casa natal y casa urbana. La experiencia de Neruda es típica de lo que en adelante se llamará poesía lárica: nostalgia del terruño frente a la aversión por el entorno urbano (mezclada con algo de fascinación) y sus posibilidades de bohemia artística y socialización. La casa natal, y la experiencia de la provincia, se concretan en la mitificación de la naturaleza originaria del sur de Chile, versus la enajenación de la vida metropolitana: filosofema que se incuba desde la más remota Antigüedad en Occidente, pero que alcanza su máximo desarrollo en la crítica de los primeros intelectuales posrománticos, tanto en Europa como en América del Norte y del Sur (Ralph W. Emerson, José E. Rodó y José Martí, por ejemplo). En palabras de Schopf:

Esta casa, y su entorno natural y social, se contraponen radicalmente al ambiente de la gran ciudad en que predomina "un olor atroz de gas, café y ladrillos". En sus calles y callejones se desplazan "trajes" y no personas, como en la Frontera; seres anónimos, alienados y hostiles y no el padre, los deudos, los ferroviarios evocados épicamente como "centauros del camino (Neruda, cit. en Schopf 38). La experiencia del retorno a la Frontera, moldeado ya el poeta por la ciudad, se recoge en la nostalgia de la generación de Jorge Teillier, Efraín Barquero y otros.

Por otro lado, la concepción darwinista de la lucha por la sobrevivencia cobra en la experiencia poética tintes naturalistas y sociales. Aparecen la ansiedad y la angustia en los poemas de Crepusculario y Residencia en la tierra: "Su rechazo de la alienación moderna, aún muy mediatizado literariamente, encuentra apoyo en su intensa ligazón con la naturaleza (deformada en partes del libro por una interpretación panteísta)." (Skármeta 39). Poemas como "Desespediente", "Walking around", "Un día sobresale" o "Caballero solo" tematizan explícitamente la vida en la ciudad. Están impregnados de su atmósfera negativa y expresan experiencias directas, inmediatamente vividas por el poeta. Esta visión afecta, igualmente, la percepción del tiempoespacio que genera el cronotopo del tiempo lento y circular (rústico) frente al tiempo rápido y lineal de la vida moderna. A ello se une la experiencia de la desvinculación y anonimidad radicales. En términos de Georg Simmel: 
soledad e impersonalidad que determinan un estado mental o ethos neurótico ${ }^{12}$. Plantea Schopf:

El poeta se siente separado violentamente en la ciudad: separado -desgarrado de la naturaleza (que resurge principalmente en su recuerdo)- separado del prójimo - que es hostil y cerrado- y, por último, separado de sí mismo. Su percepción de la realidad y de sí mismo se hace dramáticamente fragmentaria (Schopf 40).

De más está decir que esta fragmentación o dislocación se manifiesta en el plano de la enunciación y composición poéticas. El filosofema de la vida urbana como espacio de alienación y degradación se desarrolla en Occidente en la medida en que la naturaleza, expulsada o relegada por la ciudad, es mitificada progresivamente hasta alcanzar el carácter de paraíso perdido. El poeta deambula por la ciudad constatando todos los lugares comunes del pesimismo social. Específicamente, la negación y ocultamiento del cuerpo: "[...] trajes y vestuarios que, en el espacio público, ordenan y jerarquizan socialmente a las personas, rebajando su individualidad y su cuerpo. El erotismo está también gravemente adulterado" (Schopf 41). Obviamente, esta crítica intuitiva no expone lo que sería la contrapartida de la noción de cuerpo en una sociedad no urbana: ¿Cuerpo expuesto? ¿Desnudo parcial o total? nos preguntamos.

El compromiso político de Neruda lee la ciudad como espacio de opresión y explotación capitalista. "El poema ["Oda de invierno al río Mapocho"] destaca la miseria y la injusticia social imperantes y concluye con una invocación alegórica a que las aguas fecunden la "semilla del hombre" (Schopf 41). Sin embargo, el espacio urbano no es en exclusiva el espacio de explotación capitalista: "[...] en Canto General los espacios en que al poeta se le hacen más ostensibles la injusticia social y la explotación capitalista y que elige para su denuncia son las minas de cobre y salitre en el Norte de Chile y las minas de carbón del Sur de su patria" (Schopf 42).

A la larga, el sujeto nerudiano introyecta el espacio urbano sin olvidar sus orígenes. La ciudad entra en él y se convierte en su hábito. Permanece como contradicción no resuelta, que se concreta, como en la gran mayoría de los productos literarios de la época, especialmente de los escritores progresistas, en una imagen de ciudad utópica. Schopf observa que, en el 
discurso de aceptación del Premio Nobel, Neruda profetiza: "Sólo con una ardiente paciencia conquistaremos la espléndida ciudad que dará luz, justicia y dignidad a todos los hombres". Es decir, un deseo, legítimo y justo, pero siempre utópico.

La poesía de Nicanor Parra plantea el mismo patrón de asombro y desconfianza provinciana frente a la metrópoli. Desde muy temprano, el espacio rural o aldeano es visto como un ethos en transición que está quedando en el pasado, o mejor dicho, como señala Henri Lefebvre ${ }^{13}$, se ha redefinido como periferia sometida a otro cronotopo, muy alejado de la utopía naturalista: “[...] el espacio rural de Parra estaba ya incorporado desde la Colonia a la vida histórica de la República." Más adelante, Federico Schopf afirma:

El espacio rural está también contaminado por la ideología y las estructuras socioeconómicas de la Modernidad. La aldea rural de la provincia de que proviene el antipoeta exhibe huellas de tiempo transcurrido, trasunta pequeña historia y en ella dominan formas de vida tradicionales (o tradicionalmente provincianas) (Schopf 43).

Acertadamente, Schopf reconoce que "es en los antipoemas en que la experiencia urbana del sujeto parriano encuentra su expresión más adecuada. Todavía más: la forma antipoética misma surge de los shoks [sic] sucesivos de este sujeto en su deambulación por la gran ciudad" (Schopf 44).

El antipoema no surge de la tradición costumbrista de la visión lárica, sino que, en síntesis, "[e]l sujeto antipoético está articulado en la ciudad" (Schopf 44). Parra profundizaría la crítica ideológica de la sociabilidad urbana, dominada por el aspiracionismo burgués, que operaría según mecanismos de ocultamiento, inhibición y marginación de las clases no capitalizadas. El antipoema ironiza, satiriza y desublima el orden burgués y sus representantes: estado, policía, clases dirigentes, racionalidad científica, etc. Curiosamente, las temáticas, voces y lugares comunes de la vida urbana se convierten en forma y tema de los antipoemas: "El espacio característico de los antipoemas es urbano: al mencionado parque inglés se agregan fuentes de soda, hipódromos, colegios, pensiones, iglesias, cines, quintas de recreo, barrios elegantes, locales comerciales, edificios, fábricas, restaurantes de lujo, etc." (Schopf 44).

Por otra parte: "El antipoeta compone sus textos con restos, con lo que tiene a mano: él y sus antipoemas están articulados, profundamente imbricados en 
el contexto urbano" (Schopf 44), pues se alimenta de titulares de periódicos, eslogans, frases retóricas, arcaísmos, lenguaje vernacular. Para ejemplificar esto, Schopf analiza el antipoema "Los vicios del mundo moderno" como una invectiva totalizadora contra la legalidad de mundo, distorsionada globalmente por una actualización paródica del tópico del Mundo al Revés, permitida y hasta fomentada por el establishment. Una de las principales características de la experiencia urbana, la fragmentación y la inefabilidad de un horizonte siempre cambiante y aparentemente total, ya aparece como un rasgo estilístico compositivo en las Iluminaciones de Rimbaud; en Parra, El antipoema no tiene principio, medio o fin en el sentido del poema tradicional:

La experiencia del tiempo desde la que surge esta (des)estructuración es discontinua. La vida y la experiencia se hacen fragmentarias. La denuncia de las alienaciones o deformaciones -diversificadas en una cantidad indefinida e incontrolable de "vicios"- no puede ser completa: todo lo más aspira a impresionar o convencer por su intensidad (Schopf 45).

Es decir, el antipoema concreta en sí mismo el cronotopo de la simultaneidad sublime, la "totalidad inaprehensible" y repelente al mismo tiempo, de un espectáculo sin fin y (aparentemente) sin principio. De manera lapidaria, Schopf concluye: "No hay resignación, adecuación en la actitud del antipoeta. Citando al propio Parra: "Pero no: la vida no tiene sentido" (Parra cit. en Schopf 46).

En relación con el sujeto y la poesía de Enrique Lihn, Schopf reconoce que "[e]s un sujeto (de)formado íntegramente en la capital". Y más adelante: "La vida del sujeto de su escritura transcurre en la ciudad. Esta no es mero escenario de su habitación y desplazamientos, sino un medio que lo traspasa y conforma" (Schopf 48). En la poesía urbana de Lihn aparecen los tópicos del solitario en la urbe y de la muchedumbre solitaria (Edgar Allan Poe, "The Man in the Crowd" (1840), Nicolás Gogol, Cuentos de San Petersburgo(1830-1840), David Riesman, The Lonely Crowd (1950): "La ciudad de Enrique Lihn es una ciudad de individuos solitarios. Ellos son los otros, los sujetos que ocupan las casas y se mueven por las calles, realizan negocios, se adelantan en todo, poseen todo y conservan celosamente la distancia" (Schopf 47).

Sumado a lo anterior, los tópicos de apariencia versus realidad, progreso versus mendicidad, se desarrollan en el poemario A partir de Manhattan (1979): 
[...] el doble peso de la desarticulada ciudad dependiente del peso de lo que es y lo que aparenta, de la autenticidad y la copia está abrumadoramente presente en el contenido de estos poemas; en cierto sentido, ella es uno de sus continentes: encierra al poeta como una pesadilla: con sus puertas y calles abiertas (Schopf 48).

Resulta interesante la propuesta del autor del artículo al relacionar la crisis del habitar moderno, reseñada por Lihn y tantos otros, como la pérdida del espacio privado del sujeto, su fusión o confusión con lo público, junto con la invasión del exterior social constituido por circuitos de discursos, medios, artefactos, imágenes y mensajes:

Su interioridad está invadida por la exterioridad social: el espacio privado está no sólo colmado por los contenidos, los mensajes de los medios de comunicación al servicio de la ideología dominante; incluso los medios han llegado a ser parte esencial del mensaje, sino que la interioridad misma de los individuos está fabricada y ocupada por ellos. Es decir, el individuo es un pseudoindividuo [sic]: es en su realidad concreta la masa (de)formada por esos medios (Schopf 50).

Estamos frente a un diagnóstico pesimista que comparten la mayoría de narradores y escritores de las generaciones neorrealistas en Latinoamérica, y que se traspasa a las cohortes siguientes (Fernando Alegría, Ariel Dorfman, Jorge Edwards, José Donoso, entre otros). Resulta característico de este análisis pesimista el hecho de que se desconfía de la técnica y de los medios masivos de comunicación. Demoniza la televisión como un objeto invasivo del espacio privado de la pareja heterosexual como un espejo alienante que retrae al sujeto a la indefensión del hombre prehistórico, reemplazando ritos colectivos con ritos de enajenación propiciados por la ideología dominante: "Como los primitivos junto al fuego el rebaño se arremansa/ atomizado en la noche de las cincuenta estrellas, junto a la televisión/ en colores/ De esa llama sólo se salvan los cuerpos" (Enrique Lihn, "A partir de Manhattan", cit. en Schopf 50).

La posibilidad del retorno a la infancia (motivo recurrente en autores de la generación de 1960) está cerrada por la pérdida precoz de la inocencia y el impacto de la ciudad en el provinciano que retorna a sus lares. La fragmentación de la experiencia urbana conlleva la atomización de los recuerdos entrañables y familiares. Se llega, así, al motivo de la desmemoria como contenido recurrente en la poesía de Lihn y su generación. Aunque no incluido en el estudio de Federico Schopf, el poemario El Paseo Ahumada 
(1983) ejemplifica esta situación existencial del sujeto contemporáneo, agravada por la presencia de la represión política y una profundización del modelo económico capitalista.

\section{SOLEDAD BIANCHI (I). LA ESCENA POÉTICA URBANA (1987)}

En esta comunicación, leída en la Universidad de Roma en 1984, la profesora Soledad Bianchi (1948) plantea una revisión de la escena literaria de los años setenta y ochenta, con especial atención a la irrupción de propuestas discursivas durante la dictadura en Chile. La importancia de esta conferencia es el hecho de que se asume, como cosa ya zanjada, la naturaleza cívica de la literatura, pasando del análisis de la ciudad como espacio representado a la situación de enunciación, creada por el acto mismo del decir ficticio, y de ahí al receptor ideal, devenido en real:

[...] mientras la ciudad puede o no aparecer en una obra, es preciso trascender este espacio representado y considerar asimismo tanto el espacio de la escritura como el espacio de la lectura, tríada inseparable e inherente al espacio literario donde el orden espacial no se corresponde con el orden lógico ni con la causalidad-cronológica (Bianchi 1987, 172).

Bianchi cita obras estrictamente contemporáneas y sus autores: Gonzalo Millán, Tito Valenzuela, Jorge Montealegre, Mauricio Redolés, Rodrigo Lira, Carlos Cociña y Enrique Lihn. Como principal característica de la obra poética de estos autores está el hecho de que erigen ciudades textuales que pueden referir a ciudades contemporáneas extranjeras, pero que en gran medida aluden a metrópolis chilenas evidentemente ficcionalizadas. Ejemplo de ello son La ciudad (Millán), Daduic-Ytic (Valenzuela), Cipango (Tomás Harris). Estos autores son considerados, desde el punto de vista de la enunciación, como refundadores de ciudades míticas, las que retornan a sus orígenes y confrontan su destino en un escenario apocalíptico.

Antes de seguir adelante, hay que reconocer que Bianchi establece un punto de partida semejante al de Federico Schopf, al identificar el ingreso de la ciudad al imaginario literario chileno en generaciones anteriores, ya sea por la actitud nostálgica o la extrañeza del exilio que sufren algunos de estos escritores: 
La urbe atrae y se asume o se rechaza cuando se añora una mítica naturaleza del espacio de la infancia, y la poesía la incorpora o la silencia. Otras veces, se hace una poesía urbana pues la producen poetas ciudadanos que construyen su mundo poético como tales, sin que obligadamente necesiten explicitar la ciudad, como Rosamel del Valle (1900-1963), Humberto Díaz Casanueva (1906), Enrique Lihn (1929), Oscar Hahn (1938), Manuel Silva Acevedo (1942), Waldo Rojas (1944), Tito Valenzuela (1945), Gonzalo Millán (1947). (Bianchi 1987, 172).

En la escritura de estos autores, y más en profundidad en los casos de Valenzuela y Millán, Bianchi empieza a constatar recursos vanguardistas que intervienen la tradición de la poesía escrita con juegos de grafía y fonía, rupturas de la linealidad y alteraciones creativas en la disposición de la página, a menudo usando recursos visuales. Tanto en Millán como en Tito Valenzuela, la enunciación poética instala una situación de comunicación apelativa, es decir, dramática; el Yo poético mismo se abisma y se fragmenta en multiplicidad de voces que el lector debe armonizar. Así, en el texto "Poema condicional" de Valenzuela, Bianchi afirma que:"[Daduic] pertenece al pasado del actorhablante que en el poema "Las ruinas" hace ver la docena de asaltos que la destruyeron [a la ciudad] hasta que "las luchas internas" le hicieron perder su propia identidad, pues "precipitaron su incorporación a otro imperio" (Valenzuela, cit. en Bianchi 1987, 174).

La presentación de la urbe como espacio de conflicto, proyectado hacia un pasado sincrónico (la Conquista, la Colonia) se asocian con una catástrofe existencial análoga a la pérdida de sentido de la poesía en particular, y de la palabra en general, en el período de la dictadura. Asociadas con la realidad fragmentada, heterogénea del ethos urbano moderno, aparecen visiones apocalípticas, reflexiones metapoéticas sobre el deber de la poesía y una propuesta de relación analógica entre el decir, la escritura de la ciudad y la construcción de artefactos verbales como maquetas y juguetes ${ }^{14}$.

La visión pesimista de la urbanidad se proyecta sobre los artefactos propios de la sociedad de consumo: objetos fetichistas, personificados, animalizados, que se venden a precio de costo en el Paseo Ahumada (Lihn). Surge la imagen tópica de la ciudad-selva, laberinto, espacio de extravío y ruina que se proyecta

14 Esta noción es llevada a sus últimas consecuencias estéticas por Ricardo Piglia en su texto El último lector (2005). 
al mundo doméstico (Millán, Vida, 1984). Sin embargo, recogiendo una observación de Rosalba Campra ${ }^{15}$, la ciudad construida textualmente opera como palimpsesto en que se van superponiendo capas: ciudades infernales, centros históricos, barrios, plazas; ciudades coloniales, precolombinas, contemporáneas; microcosmos y macrocosmos, centro y margen, modernidad y premodernidad. La crítica a la mágica solución urbana del Paseo Ahumada, genialmente concebida por Lihn, introduce la representación del propio poeta como "habitué" del paseo, lector y consumidor, a la vez que "parahéroe" de la protesta callejera.

La densidad de referencias contextuales, intertextos y guiños al lector se repite explícitamente, según Bianchi, en la obra de Jorge Montealegre. En "Domicilio conocido", el poema se expande desde el domus hasta la ciudad entera. Se dirige a un receptor implícito "que debe colaborar con el sujeto de la escritura aportando al texto sus conocimientos sobre cada uno de los sitios aludidos y su historia o comprendiendo los términos del código nacional, los chilenismos. El destinatario participa igualmente al deducir la ironía y los guiños del "yo" con quien dialoga dentro del espacio textual" (Bianchi 1987, 183).

Finalmente, la ciudad no solo es tratada como asunto literario o elemento estructurante, sino también como referente concreto para actos performativos "[...] pues también es poesía urbana aquélla realizada y producida "en" la urbe que, en esta ocasión, es considerada un texto y, a su vez, se transforma en obra" (Bianchi 184). De este modo, Bianchi recupera la obra de Lotty Rosenfeld, Cecilia Vicuña y Raúl Zurita, entre otros, quienes ocupan la ciudad de manera rupturista, interrumpiendo la rutina e introduciendo en el tiempo del trabajo y consumo una cesura crítica a través de acciones de arte e intervenciones desautomatizantes.

En su conclusión, luego de revisar la obra estética de poetas y artistas visuales, Bianchi observa la proliferación de significados negativos en el imaginario urbano correspondiente a los años setenta y ochenta en Chile: Imágenes como baldio (Harris), herida (Millán), ciudad podrida (Valenzuela) evidencian " [...] que la urbe adquiere rasgos negativos que se corresponderían con las limitaciones del hombre que la ha construido y que la (mal) habita, pues ella ha adquirido y desarrollado atributos monstruosos que impiden que su constructor se sienta a gusto allí y que la reconozca" (Bianchi 1987,185). 
Más allá del contexto histórico en que fueron escritas, estas obras literarias se instalan en una visión de mundo en que la ciudad es una amenaza y un infierno moderno, idea que se remonta a la crítica de la era tecnológica realizada por los intelectuales del siglo XIX, tanto en Europa como en América del Norte y Latinoamérica.

\section{GLORIA FAVI (I): LAS ACCIONES DE HABLA EN UN TEXTO DE ENRIQUE LIHN (1992)}

El artículo de Gloria Favi, académica de la Universidad de Santiago de Chile, se inserta en una corriente de estudio literario que se benefició de adoptar las teorías de la pragmática lingüística de John Searle ${ }^{16}$. La teoría de los actos de habla, aplicada al análisis de la poesía, añade un valor epistemológico a la instancia de enunciación y su relación con el discurso, así como su función en un circuito comunicativo. Aplicando esta categoría teórica a una lectura del poemario El Paseo Ahumada, de Enrique Lihn, Favi reflexiona sobre la coherencia entre las ideas de Lihn sobre la poesía "situada" y su visión del poema como lugar de encuentro de textos, intertextos y perspectivas de recepción. Favi cita al propio autor:

Escribí El Paseo Ahumada para incorporarme de alguna manera a lo que pasa allí, es un esfuerzo para dar forma en las palabras, a la situación de emergencia que vive el país". "La poesía es como se sabe una protesta contra la realidad, presupone el extrañamiento y el distanciamiento. $\mathrm{Y}$ esa protesta puede ser un acto perfectamente realista" (Lihn, cit. en Favi 1992, 91).

Considerando la particular situación histórica de Chile en la década del ochenta (dictadura, persecución política, censura, desinformación), el esfuerzo de Lihn por instalar un artefacto literario como El Paseo Ahumada equivale a un acto estético y político (es fama que el poemario fue "lanzado" en el mismo Paseo). Afirma Favi: 
No lo que se dice, sino las acciones que se hacen al decir, confieren la fuerza ética del habla; estas acciones nos permiten inferir quién es el hablante y cuáles son las circunstancias enunciativas que enmarcan su conducta lingüística. Son éstas, en líneas generales los postulados teóricos de la Pragmática del Discurso, a los cuales nos adherimos para proponer un modo de lectura para El Paseo Ahumada, e intentar demostrar que la poesía es una acción ilusoria que intenta mejorar la existencia produciéndola en el lenguaje (Favi 1992, 92).

El artefacto llamado Paseo Ahumada opera, entonces, en dos niveles: como reescritura de un espacio público leído críticamente en tanto y en cuanto discurso del poder político, y como objeto poético que interpela al lector real proponiendo una apelación directa al receptor a través de estrategias paródicas e irónicas:

De esta forma, el uso mimético de la escritura periodística, el habla de los vendedores callejeros, el decir de la gente y, en general, el emparentar la poesía con las jergas más vulgares, nos está demostrando que la literatura ha sido contaminada con la impersonalidad y el artificio propio de la red ideológica implícita en los medios de comunicación de masas (Favi 1992, 92).

Favi asume la visión apocalíptica de considerar las voces de la ciudad, los discursos y modos de habla de la comunicación de masas como desastres comunicativos que contaminan la poesía (¿sublime?) de la tradición anterior al desastre político. Opone artificio, impersonalidad (de los medios de masas y discursos oficiales) a la (¿espontánea?) naturaleza de la poesía en tiempos de libertad (¿democracia?). Los actos de habla son voces impostadas o simulacros de un discurso del sujeto "otro" y marginal. Como Neruda (cuya escritura es parodiada en el poema "Canto general" del propio Lihn), el hablante del Paseo Ahumada presta su voz al sujeto marginal por excelencia, El Pingüino ${ }^{17}$, para enunciar un canto afásico, es decir, deteriorado patológicamente ${ }^{18}$. La metáfora también es usada por Millán en La ciudad, cuando se insiste en el

17 Artista callejero que frecuentaba el Paseo Ahumada en los años ochenta. Su fotografía ilustra la primera edición del poemario del mismo nombre.

18 El "Pingüino" fue un artista callejero que tocaba una monótona percusión a la salida del Metro Universidad de Chile, a mediados de los años ochenta. Lihn inserta una fotografía del mismo en la edición original del poemario. 
vivir "amordazados" y en que el lenguaje está "enfermo". Sin embargo, hay que tener en cuenta que el acto de impostación y parodia de los discursos oficiales, tanto como la espectacularización del habla marginal, solo es posible a partir de la simulación del acto de habla. El artificio de Lihn se enriquece precisamente de esos y otros artificios -incluida la tradición, devenida en objeto de parodia- para crear una nueva situación comunicativa, que interpela al lector tanto como al ciudadano en tanto y en cuanto consumidores de parodias.

La "excentricidad"19 de la enunciación, la emulación de actos de habla interpeladores, amenazantes o patológicos, inviste al hablante como un sujeto que se hace cargo "de ese decir [decadente] para desmitificarlo desde una percepción irónica, desvalorizarlo, desprestigiarlo o impugnarlo, según el caso" (Favi 1992, 92). Como conclusión general, Favi establece, en este punto, que el texto poético inscribe intratextualmente sus propios contextos socio-históricos y ciertas prácticas de comportamiento social en nuestro continente. Aunque el texto crítico no refleja una posición ideológica sobre dichos contextos, se puede inferir un diagnóstico del estado de conciencia del hombre latinoamericano contemporáneo y de los valores comunes y específicos que sostiene el habla de un cierto grupo social. De esto depende la coherencia del texto, es decir, de los sobreentendidos convencionalmente conocidos por el hablante y receptor en el momento de la enunciación:

Debemos confesar nuestra seducción por un texto que incorpora en forma explícita, pero oblícua (sic), con un excedente de sentido que hay que inferir, las circunstancias de "un espacio imaginario horrible", al utilizar el habla local y las referencias periodísticas de la época, sin abandonar la práctica de la literatura y su angustiosa relación con el lenguaje (Favi 1992, 96).

Un mundo urbano grotesco y degradado, semejante a un teatro del absurdo en tres dimensiones. Un espacio vigilado y cautelado, expresado en clichés del habla cotidiana y el sentido ambiguo de las metáforas creadas a partir de ésta. Así se conforma, a pesar de todo, la construcción textual que persiste como testimonio de la resistencia al olvido de una época, desafiando a nuevas generaciones de lectores, que jamás conocieron el Paseo Ahumada de 1985,

19 Concepto usado por Carmen Foxley en su estudio Enrique Lihn, escritura excéntrica y modernidad (1995). 
para realizar un nuevo trabajo hermenéutico. La coherencia de este y otros proyectos creativos de Lihn se refleja en el siguiente ensayo de Gloria Favi.

\section{GLORIA FAVI (II): ENRIQUE LIHN, CRONISTA (Y LECTOR) DE UNA CIUDAD (1993)}

La crónica urbana es uno de los géneros mixtos más importantes generados por la modernidad ${ }^{20}$. Instala la figura del cronista como sujeto y enunciador, habitante y lector de la ciudad. El cronista distingue y discierne los espacios y sus correlatos temporales, en tanto lugares geográficos y simbólicos retóricamente construidos. Luego los somete a técnicas de parodia o ironía que producen el distanciamiento o la empatía cómplice del lector, según sea el propósito ${ }^{21}$. Sin embargo, este concepto moderno se superpone al interés despertado por las crónicas de conquista y colonización de América, escritas desde el siglo XVI en adelante, en la teoría literaria de los años noventa. Al hablar de crónica, por lo tanto, Gloria Favi superpone el modelo de la crónica de Indias (basado en el panegírico y en la gesta) con el artículo o cuadro de costumbres surgido en la sociedad de masas a finales del siglo XIX (basado en el ethos burgués y en la vida cotidiana de las capas medias y bajas de la sociedad). Se hace complejo distinguir, especialmente en la escritura de Enrique Lihn, el carácter paródico de la conexión entre la ciudad colonial frente a la hibridación (o mimetización) de la poesía contemporánea con el carácter testimonial y resistente de las crónicas contemporáneas. Así lo reconoce Gloria Favi: “[...] nos resulta tentador, tratándose de la obra de Enrique Lihn, indagar en qué medida este concepto genérico-crónica, ha sido desarticulado, transgredido y constantemente negado en su producción

20 Consideremos los artículos de costumbres, las notas de viaje y las columnas periodísticas, tanto en Europa como en Latinoamérica, desde Charles Dickens (Sketches by Boz), José Joaquín Vallejo ("Jotabeche") y Mariano José de Larra ("Fígaro") hasta Salvador Novo (Nueva grandeza mexicana), Roberto Arlt (Aguafuertes porteñas), Jorge Assís (El Buenos Aires de Oberdan Rocamora) y Pedro Lemebel (La esquina es mi corazón).

21 "La crónica -como el periódico mismo- es un espacio enraizado en las ciudades en vías de modernización del fin de siglo. Esto, primeramente, porque la autoridad (y el valor) de la palabra del corresponsal se basa en la representación de la vida urbana de alguna sociedad desarrollada para un destinatario deseante -aunque a veces ya temeroso-de esa Modernidad" (Ramos 113). 
última, El Paseo Ahumada (1983) y La aparición de la Virgen (1987)" (Favi 1993, 131).

Frente al carácter testimonial y sincrónico de la escritura de El Paseo Ahumada, desarrollado en un artículo anterior, Favi plantea:

Nos preguntamos ¿cuáles son las intenciones del discurso transgresor en los textos de Lihn?; él afirma, "yo trabajo en el plano de la antiutopía, verifico un mundo que es insoportable. Quiero ser lo más destructivo posible. No fabrico utopías, ni ofrezco soluciones, doy a conocer las fallas". En general, la obra de Lihn "desmitifica la retórica del poder y pone al descubierto las distorciones (sic) de la palabra en los mecanismos convencionales del discurso panegírico" (Lihn, cit. en Favi 1993, 131).

Asumiendo que la construcción de El Paseo Ahumada fue visibilizar el "milagro económico chileno", instalando a Santiago en el eje de modernización de espacios públicos cosmopolitas (Buenos Aires, París, Estados Unidos), Lihn desmitifica la noción de espacio público abierto (como abierta es la economía de mercado), edificando una enunciación crítica -una pragmática de comunicación desde el margen (centro mismo)- del centro histórico de Santiago. El Paseo Ahumada se muestra como un espacio carnavalizado, que alberga una nueva mendicidad y nuevas voces que el poeta recoge como restos, ruinas y baratijas sociales a la manera de las "novedades del año" compradas en Taiwán y vendidas por el incipiente comercio callejero. Y, sobre todo, dialoga (trata de dialogar) con los mendicantes, e imposta la voz por lo que no sostiene discurso alguno, y resiste, en concreto, los embates de la represión en el Paseo mismo, devenido en lugar de "escena primaria callejera"22.

Por otra parte, cabe preguntarse: la desmitificación de la crónica, ¿desde qué relato, necesariamente mítico, opera y se despliega? ¿No es la parodia del mito igualmente una re-mitificación? Evidentemente, Lihn desmitifica la crónica como discurso del poder; recuperando el mito moderno del poeta como adalid de una conciencia contestataria que denuncia, desmonta y reinstala una ideología del panegírico y sus realizaciones prácticas. Dice Favi:

22 El concepto de escena primaria callejera es de Marshall Berman Todo lo sólido se desvanece en el aire (1982). Lihn se representa a sí mismo en uno de los muchos "sittings" (sentadas) realizadas en el Paseo, y se ve como un "para-héroe" espectacularizado por la televisión extranjera que registra la carga de los policías contra los manifestantes. 
La elocuencia panegírica se convierte en esta situación en una virtud para sobrevivir, estos discursos insinuantes dotados de una persuasión casi demoníaca, dan cuenta de un estado del mundo utilizando el criterio clásico de "lo visto y lo vivido", el mundo representado, es producto de la experiencia personal y la observación directa de la realidad (Favi 1993, 132-133). (La puntuación errática está en el texto original).

Llama la atención que la autora del artículo no reconozca, en este punto, el trabajo de ficcionalización lírica y autoparodia que ella misma ha identificado en su artículo anterior, y que el poeta mismo deja en claro: el mundo representado no es la realidad, sino una distopía o antiutopía de la misma. El sujeto se reconoce ficticiamente como habitante de esta maqueta simbólica que es la ciudad hecha de palabras, y como habitué de una escena social referencial, el Paseo Ahumada, con su Banco, sus cafés y sus tiendas comerciales.

Si bien es cierto que la alabanza a la tierra y al héroe es reemplazada por el lugar horrible y el antihéroe, el habitué del Paseo reconoce (y representa), por ejemplo, la "estética del vivac", es decir (según Favi) la "belleza de la represión” (Favi 1993, 133). El mundo del Paseo Ahumada es de una marginalidad resistente a imágenes tópicas impuestas por los medios de masas:

El comportamiento verbal del narrador está determinado por la experiencia y la reflexión sobre el acontecer; [...] además de mostrar con claras intenciones desvalorizadoras, la condición bestializada [...] de los habitantes de este reino. En el nivel de la recepción, creemos que existe una implícita alusión a cierto poder omnímodo que impone formas y normas de conducta social (Favi 1993, 134).

La tesis de Gloria Favi apunta a la caracterización de El Paseo Ahumada como "anti-crónica", es decir, negación sistemática de modelos europeos o centrales de narración de empresas heroicas y fundacionales. Por el contrario, el poemario de Lihn sumerge al lector en un espacio cotidiano en que los mitos épicos, apropiados por quienes escriben la historia desde el poder, son satirizados y parodiados por la saturación intertextual, los clichés y estereotipos lingüísticos, la fragmentación del verso y la impostación de voces heterogéneas, relegadas al margen de los circuitos públicos. Así:

El espacio heroico - el centro colonial- es ahora el refugio de vagos, mendigos, cesantes, artistas, oradores, magos; todos ellos se desplazan negando el eje geográfico de la conquista, desde la Alameda de las 
Delicias hasta la Plaza de Armas, en una meritoria huida de la fuerza policial, y es esta gloriosa marcha la que les permite sin mandato real registrar e informar detalladamente la topografía, clima, productos, flora y fauna de este Reino de Chile (Favi 1993, 134).

Junto al carácter de "anti-crónica" de El paseo Ahumada, aparecen otros tópicos propios de la actitud de "intelectual contra la ciudad": el agotamiento del lenguaje, propio de la visión apocalíptica del artista de los ochenta; el habla del político y el poeta coincidente con acciones y gestos grandilocuentes, construidos sobre una base [contextual] vacía; la nostalgia y melancolía escépticas propias de un paseante integrado, a regañadientes, a la sociabilidad urbana emergente; las referencias en clave a figuras políticas y populares del período (sacerdotes adictos al régimen militar, predicadores callejeros, músicos ambulantes, mendicantes lisiados [cuchepos]. Concluye la autora:

Ciertas ornamentaciones, las anacrónicas marcas textuales, - Alameda de las Delicias y Santiago del Nuevo Extremo- se constituyen -a mi juicio- como voces nostálgicas, para manifestar su desacuerdo por las destrucción arquitectónica, ecológica y moral [de la dictadura] (Favi 1993, 135).

En síntesis, los artículos sucesivos de Gloria Favi leen la poesía de los años ochenta de $\mathrm{Lihn}^{23}$ como una acto de resistencia pragmático (acto de habla y parodia del género crónica) como un programa de denuncia no solo testimonial, sino que también autorreflexivo, polifónico y dialogante, frente a un devenir urbano contemplado como catastrófico y decadente, aunque no quede claro (pero puede inferirse) de qué época mejor y de qué mejores tiempos es la decadencia moderna del Chile neoliberal.

\section{SOLEDAD BIANCHI: PAISAJES: CIUDAD PRESENTE/ CIUDAD DISTANTE (1999)}

En este artículo, Soledad Bianchi vuelve a los temas en torno a la representación estética de lo urbano, agregando una preocupación por la recepción activa,

23 En este artículo, si bien lo menciona, la autora no analiza el poemario "La aparición de la Virgen" de Lihn. 
tanto del lector como del habitante. Se interroga sobre la sociabilidad chilena de la transición a la democracia, y profundiza en el concepto de paisaje que las artes visuales -y la literatura que usa procedimientos visuales- revela en su movimiento por la ciudad metropolitana. El texto mismo está dividido en secciones llamadas "paseos", con lo cual la autora parece enfatizar el carácter móvil, líquido y descentrado de su lectura crítica de la sociedad y los circuitos artísticos que ésta alberga. Más aún, se relee a sí misma y constata el cambio del estatuto del lector crítico (o académico), de receptor pasivo y privado a lector activo y colectivo de una ciudad que posee una gramática y erótica que los ciudadanos descifran y realizan día a día ${ }^{24}$.

Porque yo, como ciudadana, cotidianamente anclo, viajo y atravieso el texto urbano, pero también recorro y transito otros textos: algunos escritos, entre ellos. Pues así como el fláneur de Baudelaire se paseaba por la ciudad; yo, como lectora, soy una paseante, una fláneuse que deambula por líneas; se detiene en las pausas, o no las respeta; completa intervalos y socava vacíos; relaciona los trazos; descubre esquinas y trayectos; inventa; tiende y corta puentes; vaga; lee y escribe [...] Yo vago, dije, porque así como merodeo por el texto, como una vagabunda, como una vaga, también divago, imagino, fantaseo, desconecto, enlazo (Bianchi 1999, 148).

Bianchi inicia su primer paseo evocando la imagen del sitio eriazo, erial o baldío, que se muestra en la película Caluga o menta (1990) de Gonzalo Justiniano, como:

[...] una metáfora social porque desborda la geografía para expandirse e indicar a los habitantes, a los santiaguinos y nuestros modos de relacionarnos entre nosotros y con nuestra ciudad, a nuestras indiferencias, privatizaciones, nuestro negarse a reconocer, nuestra capacidad para no ver lo que estamos viendo o para ignorar lo que sabemos, a nuestra hipocresía y arribismo (Bianchi 1999, 147).

Bianchi está visualizando el erial marginal, la ruina edificada, como el heterotopo de una ciudad que se ve a sí misma a partir del modelo de "Sanhattan", que, a su vez, es emulación (en el sentido de simulación) de las

$24 \quad$ Hay en este artículo de Bianchi resonancias claras de la conferencia "Semiología y urbanismo" de Roland Barthes (1967). 
capitales financieras del Primer Mundo. La autora/ lectora trata de controlar su fascinación, rayana en el rechazo, por la ciudad moderna. Entre lo que ve y lo que quisiera ver $-\mathrm{y}$ para resolver esa tensión- Bianchi recurre al viejo tópico del mundo como teatro, agravado, esta vez, por la multiplicación de niveles de reflejo de la ciudad contemporánea: "La ciudad nos transforma en espectáculo. Me miro en medio de nubes, y me admiro (no todos los días se ven las nubes en Santiago), y me desvío de mi recorrido urbano, me pierdo, me extravío por el espectáculo de la naturaleza" (Bianchi 1999, 155).

El análisis de Bianchi, como el de Favi, se centra en géneros híbridos como la crónica urbana. El máximo exponente de este tipo de discurso sería Pedro Lemebel (La esquina es mi corazón, 1997). Pero Bianchi también repara en la obra de Diamela Eltit (Los vigilantes, 1994), Gonzalo Contreras (La ciudad anterior, 1991) y la poesía del período. Según Bianchi, en el texto referido, Lemebel presenta una imagen cubista de una ciudad sin centro, un álbum fotográfico tomado por ojos homosexuales y travestis. La segmentación de una ciudad homogeneizada a través de recursos barrocos de fragmentación y recombinación visual se lee como acto de resistencia y asalto a las nuevas mitologías de la sociedad neoliberal, revelando sus mecanismos y su funcionamiento social excluyente. La visión, al igual que en Lihn, Millán, Harris y otros, es pesimista: “[...] por la visión urbana que hoy se da y por el temple desencantado para presentarla; por el desplazamiento del centro hacia periferias, arrabales y marginalidades; por el frecuente ambiente nocturno y la poca presencia del día" (Bianchi 1999, 153).

En las crónicas de Lemebel, poesía y narrativa, cada una en su registro, recogen la infinidad de voces y acentos que circulan por la ciudad, desde lo vernáculo y barrial hasta lo "latino" entendido como variación geográfica y cultural del castellano peninsular. Así lo resume Bianchi:

Podría continuar con otros fragmentos de diversos autores, o señalar títulos como La ciudad un cuerpo de citas, de Jaime Lizama; Huellas de siglo, Puente del Arzobispo o Crónicas privadas, de Carmen Berenguer; Sodoma mía, de Francisco Casas, o Vía Pública, de Eugenia Brito, pero quiero poner fin a esta parte recordando la obra citadina y ciudadana de Mauricio Redolés, quien no siempre explicita la urbe sino que la incorpora, además, en ritmos, y en voz alta, oralmente, a modo de prédica, de cantante rock, de grito promotor de mercancías, de Rap (Bianchi 1999, 153).

En todo este cuerpo de obras literarias se encuentran recursos visuales, sonoros e intertextuales que trascienden la ciudad referencial hacia la dimensión 
del soporte, el deíctico, el acto de habla o la pragmática de la lectura en complicidad con el lector y habitante. Llama la atención que, desde Poemas $y$ antipoemas de Parra (y tal vez desde antes, considerando a Neruda, según Schopf), la visión de lo urbano y lo cívico sea siempre decadente, apocalíptica, distópica. Aquella legalidad erótica, que Barthes proponía como la fuerza aglutinante de las muchedumbres en perpetuo flujo, no existe para Bianchi. Aunque lo intente, la cronista vagante no logra simpatizar con esta ciudad metropolitana, pues la asocia con la legalidad del consumo y del espectáculo: "Quisiera encontrarla hermosa, quisiera aceptar sus cambios y aceptarla con ellos repito, pero no, me parece ajena y cada día me desconcierta y me sorprende" (Bianchi 1999, 155). Este rechazo a la ciudad del capitalismo recurre a la utopía como alternativa nostálgica invocada como fantasma: frente a "otra incógnita, a otro secreto, a otro misterio, una antigua ciudad, hoy definitivamente ausente", el intelectual crítico debe reconocer que la ciudad concreta ha desplazado un espacio mítico, irrecuperable, de una premodernidad borrosa y hasta romántica. Frente a esta respuesta idealista, resulta legítimo preguntarse qué ciudad fue esta. ¿Realmente existió? ¿Desde cuándo? ¿Es una utopía fundacional, voluntariosa, programática? La respuesta solo se encuentra, al parecer, en la memoria fantasiosa de los poetas láricos, ancestrales o políticamente comprometidos con el proyecto social que la dictadura borró y dispersó.

\section{JUAN ARMANDO EPPLE: DE SANTA A MARIANA: LA CIUDAD DE MÉXICO COMO UTOPÍA TRAICIONADA (1999)}

Juan Armando Epple (1946), académico de la Universidad de Oregon, es una figura de relieve en el panorama crítico latinoamericano y chileno. Se ha especializado, entre otras cosas, en poesía chilena, el relato breve, el folletín y la novela policial. En este ensayo, Epple establece una tarea comparativa entre dos novelas icónicas de la literatura mexicana del siglo XX: Santa (1903) de Federico Gamboa y Las batallas en el desierto de José Emilio Pacheco $(1980)^{25}$. El punto de comparación está en el nivel del personaje y

25 Si bien se nombra a Santa, la mayor parte del artículo se centra en el análisis de Las batallas en el desierto. De la novela de Gamboa se dice que es "la primera novela sobre las contradicciones de la Modernidad nacional" (Epple 37). 
su desarrollo: la mujer, Santa y Mariana, desarrollado como tópico literario de consolidación de una modernización forzada a través de la imposición de un modelo económico.

Epple retoma el diagnóstico de la importancia de la ciudad como lugar de la modernidad, desarrollado por Berman, cuando afirma:

La promoción de escritores latinoamericanos que surge a la vida cultural en la década del sesenta, durante el predominio y difusión internacional del llamado "Boom latinoamericano" y sus propuestas totalizadoras sobre la identidad diferencial del continente, lo hace asumiendo como base natural de experiencias el universo cotidiano de las ciudades, espacio problemático en que convergen los vestigios de los proyectos nacionales decimonónicos y las contradicciones de la Modernidad (Epple 31).

Las generaciones siguientes "vástagos parricidas, someten a crítica tanto la herencia del pasado, los proyectos nacionales de la ciudad moderna, como las utopías de la ciudad del futuro" (Epple 31). Es decir, problematizan la oposición básica entre "naturaleza y civilización, campo y ciudad, orden nacional y orden cosmopolita, cultura letrada y cultura popular" (Epple 31), acuñando el concepto de desmodernidad (Guillermo Gómez Peña, cit. en Epple 32).

Según Epple, existe una "tradición de la representación literaria de la ciudad de México", que consiste en la capacidad de reformular los tópicos de la tradición asumiendo críticamente su carga histórica" (Epple 32). Los principales rasgos de esta desmitificación de la tradición se basan, de nuevo, en la ironía y la parodia de géneros, discursos ficticios y no ficticios, así como en la recuperación de mitologías culturales propias de cada región.

La obra de Pacheco presenta "un eje dialogante de signos culturales cuyo resultado poético es la puesta en escena de las opciones especulares de la palabra: reflexión sobre la historia como explosivo y evanescente legado humano (materia colectiva en tránsito), y sobre las facultades miméticorepresentativas del lenguaje (un producto humano también sometido al avatar del tiempo) que intenta caracterizar y fijar en la memoria esa experiencia" (Epple 32).

La representación del espacio urbano (Ciudad de México en los años cincuenta) aparece asociada con el tópico de la mujer como símbolo de una ciudad oculta o invisible. La pérdida de la inocencia y su caída desde una condición "natural" previa a la explotación de la naturaleza y los cuerpos, 
sugiere un cronotopo utópico que ya conocemos: la infancia. Por otro lado, opera "como una transferencia narrativa e ideológica donde a la mujer se la desnacionaliza (ya no es parte de la economía nacional, o no es controlable desde el país) y se la demoniza como amenaza a las tradiciones patriarcales del país" (Epple 1999, 40).

Tanto en el caso de Santa como en el de Mariana, la mujer es víctima de un determinismo asociado con etapas de transformación urbana, dirigidos por élites dominantes que introducen drásticos cambios culturales para acelerar la así llamada "modernización" (principios de siglo XX, años cincuenta del mismo siglo). La introducción de estos cambios va de la mano con la promesa de una utopía futurista que nunca llega, o que llega para unos pocos sobre la base de la explotación de una mayoría y a través de la corrupción. Así lo establece Epple:

Para JMP [José Emilio Pachecho, sic en el original] la otrora región más transparente ${ }^{26}$ se asume no como cosmovisión inclusiva sino como espacio conflictivo, huérfano de respuestas globalizadoras, de la cotidianidad histórica. Sobre todo como un estadio tensado entre dos proyectos de ciudad: entre la ciudad fundacional, articulada como imagen autosuficiente de una idea de nación, y la ciudad del futuro, que aloja la profecía secular de un locus capaz de fundar una relación ideal de convivencia social y de realizaciones humanas libres (34).

Habría que apuntar que la representación de la ciudad en la tradición literaria latinoamericana plantea, de por sí, una elección estético-lingüística que pasa por la creación de modalidades de procedimientos poéticos para mimetizar este objeto cambiante, heterogéneo e inabarcable. Así, por ejemplo, Pacheco emplea la estructura de la novela de formación de manera paródica; el punto de vista retrospectivo del narrador en primera persona y la ambigüedad del propio acto de recordar, relativizan el sentido edificante de la Bildungsroman. Ello, a su vez, se sustenta sobre la falibilidad de la memoria (otro tópico sujeto a revisión por las generaciones posteriores a José Emilio Pacheco).

Como ya hemos visto, existe una contradicción entre las utopías urbanas diseñadas en base al modelo occidental de desarrollo, y el devenir de las ciudades latinoamericanas, estratificadas a la manera de un palimpsesto. 
Pacheco está consciente de que la herramienta de la ficción aporta a la visibilización y discusión del habitar contemporáneo, pues "la palabra también deviene en registro arqueológico de la erosión del tiempo, lejos de gratificar [sic: igraficar?] una postura pesimista o derogatoria de la literatura opera como eje catalizador de una poética entendida como infatigable proceso de reescritura" (Epple 1999, 32).

Revisando la bibliografía de Pacheco, Epple identifica ciertas constantes temáticas, como el pensamiento apocalíptico (la constante amenaza de la naturaleza que se cierne sobre la ciudad), el pensamiento ecológico (defensa de la tierra a partir de cosmovisiones ancestrales), y la necesidad de volver habitable la ciudad para los ciudadanos en un contexto cosmopolita ${ }^{27}$. En el caso de Las batallas en el desierto, la opción literaria de Pacheco sería la de un testimonio ficcionalizado, pero validado por un consenso histórico de la intelectualidad latinoamericana:

Testimonio que no se reduce a la mera denuncia de los horrores de la época, sino que se configura como una angustiosa forma de la conciencia que no admite las fáciles certezas de la profecía o del maniqueísmo; conciencia, por otra parte, que es también una constante problematización del hecho mismo de escribir, de la legitimidad de la voz del poeta y de los límites de la palabra; conciencia, finalmente de que en la experiencia de esa historia el posible lector puede reconocer el rostro de su propio tiempo (Rubén Vargas, cit. en Epple 34).

Epple destaca como un hito la publicación de La región más transparente (1954), de Carlos Fuentes. Allí, Ciudad de México aparece como una estructura piramidal de desencuentro y conflicto, que, en su existencia rutinaria, se reproduce como:

[...] espacio conflictivo, huérfano de respuestas globalizadoras, de la cotidianidad histórica. Sobre todo como un estadio tensado entre dos proyectos de ciudad: entre la ciudad fundacional, articulada como imagen autosuficiente de una idea de nación, y la ciudad del futuro, que aloja la profecía secular de un locus capaz de fundar 
una relación ideal de convivencia social y de realizaciones humanas libres (Epple 34).

En Las batallas en el desierto, Pacheco resume, con distanciada ingenuidad, el relato de bienestar "ultramoderno" que surgió de la posguerra y del nuevo mapa geopolítico liderado por Estados Unidos y la ex Unión Soviética:

Para el impensable año $1980^{28}$ se auguraba -sin especificar cómo íbamos a lograrlo- un porvenir de plenitud y bienestar universales. Ciudades limpias, sin injusticias, sin pobres, sin violencia, sin congestiones, sin basura. Para cada familia una casa ultramoderna y aerodinámica (palabras de esa época). A nadie le faltaría nada. Las máquinas harían todo el trabajo. Calles repletas de árboles y fuentes, cruzadas por vehículos sin humo ni estruendo ni posibilidades de colisiones (Pacheco, cit. en Epple 34).

La degradación del proyecto-país y su devenir en distopía amnésica es paralela a (o se corresponde con) la pérdida de la inocencia y su reemplazo por una visión hipócrita sobre el poder, las relaciones hombre-mujer y la misma historia de México. La clase media, afectada por la novedad, la cultura de masas y la irrupción de la economía transnacional, transforma al locus familiar, espacio de certezas y protección, en microcosmos de enajenación política y social. Se consolida la norteamericanización de México a través de productos de consumo: cine, comida, bebidas y etiquetas. La caída de Santa y su patetismo es reemplazada por la explotación de Mariana y su desaparición física.

Esta es la lectura catastrófica de Epple, Ángel Rama, Jesús Barbero, Beatriz Serlo y otros intelectuales latinoamericanos del siglo XX. El desprestigio del metacrilato socialista, la desmitificación de la utopía de la raza cósmica de José Vasconcelos, plantean "una revisión de las utopías pedagógicas que van desde los proyectos de salvación por la cultura mestiza defendida desde el extremo sur por Gabriela Mistral, discípula de Vasconcelos, hasta las formulaciones esencialistas de los proyectos de identidad chicana en Estados Unidos" (Epple 1999, 36).

Finalmente, Epple anuncia el motivo que va a saturar el debate cultural en las primeras décadas del siglo XXI: los trabajos de la memoria y el aporte de la ficción en el proceso de repensar la historia de nuestro continente y, en 
general, de Occidente. La memoria ficcionalizada y el testimonio permitirán abrir un flanco de crítica desde la ausencia de un metacrilato válido para el proyecto emancipador e identitario latinoamericano. Así concluye el autor:

La memoria del narrador-protagonista aparece como un esfuerzo solitario que debe negociar las prerrogativas de la ficción (ese entramado ilusorio que une el testimonio de lo vivido a la invención tardía de su sentido posible) para recrear la fisonomía temporal de una ciudad destinada a cambiar antes de llegar a ser o a convertirse, como en la tradición del bolero, en un sitio propicio para la nostalgia postmodernista (Epple 42).

\section{LUCÍA GUERRA CUNNINGHAM. CIUDAD NEOLIBERAL Y LAS CRÓNICAS URBANAS DE PEDRO LEMEBEL (2000)}

En la lectura de La esquina es mi corazón (1995), de Pedro Lemebel, Lucía Guerra despliega las herramientas conceptuales de la teoría literaria con perspectiva de género para despejar la escena crítica y académica y visibilizar la escritura transgresora del autor. La obra de Lemebel se genera desde la "periferia", usando los "desechos" del habla, generando "tensiones" en la "ideología falocrática", desenmascarando la "axiología heterosexual" en un acto de resistencia y "autoafirmación" frente a la "supremacía patriarcal". Es de destacar la acumulación de este metalenguaje, pues entrega los elementos para abordar (corriendo el riesgo, a ratos, de desplazar) una escritura que desafía al canon académico tradicional. Desde un principio, Lucía Guerra rescata, como postura de resistencia, el acto de trasladar la pregunta por el ser gay a la pregunta por la función y el modo de establecer relaciones con otro. Llegar a ser gay es despejar el falso dilema del reconocerse como hacia el establecer una diversidad de relaciones originales con el otro en una dinámica de llegar a ser con ese otro. La influencia del pensamiento político y teórico de Michel Foucault es, según Guerra, evidente. Este modo de establecer vínculos se produce en el contexto de la ciudad neoliberal convertida en "loca geografía, fuga libidinal, nomadismo urbano" (Guerra 83).

Convengamos en que la ciudad neoliberal en Chile, en el año 2000, es leída como un paisaje a la manera de un "imperio de los signos" (Jorge Romero León, cit. en Guerra 73) heredero de una "supremacía de lo patriarcal, que hace de la ciudad un diseño específico: una arquitectura, real y simbólica, que evidencia una ideología particular con respecto a lo genérico-sexual. En el caso de Santiago de Chile, este diseño se remonta a un origen histórico: 
obedece, según Guerra, al propósito "masculino y masculinizante de [Pedro de] Valdivia" (Guerra 74). Citando a Ángel Rama, la ciudad es "el sueño de un orden", "un parto de la inteligencia" en un gesto fundacional ab origine, en el cual fundar una ciudad implicaba, para el sujeto conquistador, crear a partir de la nada en medio de una naturaleza aún sin historia" (Ángel Rama, cit. en Guerra 74).

Frente a este orden, la ciudad escrita por el homosexual (marginal) es el desafío de la polisemia y la proliferación de signos (barrocos) frente a la normalización del habitar. Sobre todo, es la imagen de la ciudad caótica e insubordinada que se rebela ante el orden utópico racional. Según Guerra,

[s]iguiendo la típica axiología heterosexual del patriarcado, las casas en el damero geométrico de la ciudad fueron exclusivamente diseñadas para la familia, para hombres y mujeres unidos en alianzas matrimoniales que procrearían una nueva población para el Imperio. Estructura estricta y rígida que tachó, desde sus orígenes, al homosexual (Guerra 2000, 75).

El antecedente directo de la represión a la diversidad sexual fue el discurso de la fisiología, que define al somético desde el punto de vista de la urbanidad, la psiquiatría y la criminología. Trasunto de este enfoque es la organización proxémica de los espacios:

En la ciudad, como espacio emblemático de la Modernidad republicana, la nueva oligarquía desplegó en los espacios públicos y privados una sociabilidad en la cual "lo masculino" y "lo femenino" se regían por detallados guiones performativos, que "estipulaban la diferencia entre ambos sexos a partir de modales, hábitos y tipo de lenguaje (Manuel Vicuña Urrutia, cit. en Guerra 77).

La ciudad, como señalaba Soledad Bianchi, es recorrida y leída en espacios públicos sancionados para el encuentro en términos de ocio, o para el consumo. Para el homosexual, el paseo nocturno es una exposición peligrosa en un escenario cambiante; el recorrido urbano está lleno de desvíos. Guerra cita como ejemplos del desarrollo literario de la homosexualidad en la literatura chilena a Luis Oyarzún (Diario íntimo 1995) ${ }^{29}$, Augusto D’Halmar (La pasión

29 Oyarzún "recorre los suburbios de la ciudad bajo el influjo del alcohol, sin miedo al "cogotero": "La ciudad me parecía el escenario de piedra de un drama italiano de Shakespeare. Yo mismo era un hombre del Renacimiento" (Luis Oyarzún, cit. en Guerra 80). 
y muerte del cura Deusto 1927) y Enrique Lafourcade (Pena de muerte 1953). Sin embargo, estos ejemplos son casos aislados en la literatura chilena; hay que esperar hasta la irrupción del movimiento de liberación homosexual en los años ochenta, para contextualizar y entender las crónicas de Pedro Lemebel. Afirma Lucía Guerra:

La fundación del grupo Ayuqulen (1984), Colectivo Feminista Lesbiana, del MOVILH (Movimiento de Liberación Homosexual), en 1987, y la irrupción en escena de Las Yeguas del Apocalipsis, colectivo de arte formado por Pedro Lemebel y Francisco Casas, en 1988, han transformado, de manera radical, los espacios restringidos de la cultura chilena y, por otra parte, sus medios de difusión (Editorial Cuarto Propio, Radio Tierra) han otorgado un espacio legítimo a los discursos de la homosexualidad" (Guerra 82).

La esquina es mi corazón es un conjunto de crónicas que llevan al lector a lugares heterogéneos: discotecas, barrios pobres, autopistas; condominios, bloques habitacionales, suburbios. La lectura de la sociabilidad urbana de los años noventa es semejante al análisis de Tomás Moulián (Chile actual, anatomía de un mito [1997], y Beatriz Sarlo (Escenas de la vida postmoderna [1994]). Afirma la ensayista:

En un entorno repleto de anuncios comerciales, de modelos del éxito monetario y de diversos símbolos materiales que reafirman un statu quo, el ciudadano neoliberal ha abandonado definitivamente las utopías políticas para sumergirse en otro paraíso, el del mall o centro comercial, nuevo lugar de congregación en la ciudad [...] los sectores de la clase media y la alta burguesía ya no están unidos por una doctrina religiosa o la conversación espontánea y el paseo, sino por la fiebre de la ganga y la compra en una Nación que, a través de diferentes medios de difusión, ofrece una imagen de auge y prosperidad (Guerra 85).

Lucía Guerra, como Soledad Bianchi en sus ensayos y Enrique Lihn en sus poemarios, consideran el paisaje urbano "neoliberal" como una catástrofe, y al habitante de las metrópolis como sujeto enajenado por una ideología y manipulado por la propaganda de la sociedad de consumo.

La "fachada neoliberal" esconde la pobreza generada por el sistema; "[...] la mirada del cronista ambulante en La esquina es mi corazón se detiene precisamente en estas fisuras para mostrar el contrasello de la utopía 
neoliberal, todo aquello que el proyecto económico ha relegado a la categoría de desperdicio y desecho.” (Guerra 86). Nos preguntamos, en este punto, si esta visión dicotómica (ciudad neoliberal contra ciudad ¿precapitalista?; consumo contra ¿reparto centralizado?; sujeto alienado versus ¿sujeto originario?) cierra la puerta del análisis a los numerosos matices del habitar urbano más o menos integrado, más o menos contestatario, que las generaciones posteriores han descubierto en la resignificación de los espacios cívicos. Lo que sí está claro (y eso lo desarrolla in extenso Lucía Guerra) es que la aparición del discurso homosexual en el circuito artístico del período (y hasta el día de hoy) significó una renovación de los modos de enunciación estilística, así como de los géneros tradicionales y de la tradición literaria misma. Notable es el análisis del impacto de la paraliteratura, del cine y la música popular en la escritura de Lemebel. En este punto, el estudio de una metáfora semiótica, el cuerpo como texto y la textualización de lo corporal, es iluminador a la luz de la teoría literaria posestructuralista:

Entre las figuras geométricas de calles y edificios de cemento subyace otra ciudad, la de lo sensible urbano que traspasa las nociones cartesianas de conocimiento e inserta un Yo quien llega a ser a través de su movimiento itinerante y en un constante devenir. La ciudad es así un texto de sensaciones, un signo polisémico cuyos significados pasan primero por el cuerpo que aprehende y aprende en un deambular sensorial/intelectual (Guerra 83).

Junto con aparecer otra dicotomía de larga data -ciudad aparente, frente a ciudad oculta; apariencia contra realidad-, Lucía Guerra detecta la aparición de un ethos nuevo, inestable y fluyente, que "rompe la imagen falogocéntrica [sic] que sustenta su fachada oficial [la de la ciudad neoliberal], para insertar en ella a un Yo deseante" (Guerra 83). Espacio y escenario de este ethos deseante es la calle, "microcosmos de la Modernidad", convertida en lugar de flujo de deseos y "errancia sexual", antes que espacio de consumo o simple tránsito (Néstor Perlongher, cit. en Guerra 84).

Además de la calle, en el análisis de Lucía Guerra, se destacan dos cronotopos significativos para entender la retórica de la enunciación homosexual en el espacio urbano. Los puntos de concentración, expansión y resignificación de los significantes culturales son el mercado persa y la así llamada ciudad anal. Según Guerra (elaborando el pensamiento de Perlongher): 
El mercado persa, con su mercancía heterogénea y barata exhibida en el suelo o colgada de precarios alambres, es la réplica carnavalesca del centro comercial que ha retorificado [sic] el intercambio con sus pisos deslumbrantes, su arquitectura lineal, sus boutiques especializadas y su insulsa música ambiental. El mercado persa, por el contrario, es la imagen contraespecular cargada de mambo y de ranchera, de desorden en un cambalache primitivo (Guerra 85-86).

El mercado persa aparece marcado por signos de confusión, heterogeneidad y reubicación; las prácticas económicas son el contrabando, la coima y la reducción de mercadería robada. Por otro lado, se constituye como una memoria alternativa, hecha de "rastrojos y escorias de la Memoria Oficial". Sin embargo, de estos rastrojos y desechos surge una estética del reciclaje lingüístico y simbólico que otorga identidad al sujeto gay y, en general, a todos aquellos que son o se perciben como marginales: la construcción de un personaje que emula a un ícono de la cultura popular o de la midculture (Umberto Eco), al mismo tiempo que lo parodia. Nace, en ese momento (por lo menos en Chile) la estética del cosplay, el disfraz (neo)barroco, inspirado por actores, fetiches de la cultura popular, cantantes, etc. ${ }^{30}$.

Por otra parte, la ciudad anal corresponde a un espacio de habitar degradado, constituido por bloques habitacionales, suburbios y barriadas en los que el hacinamiento, la pobreza y la exclusión reúnen a obreros, lumpen y "locas" en torno a ritos del calendario del consumo, como la Navidad y el Año Nuevo. También es el lugar del consumo de cemento ("neoprén") y cigarrillos recogidos del suelo, un espacio otro (Marc Augé) en que la clandestinidad, la delincuencia y la transgresión se resisten a la administración del Estado neoliberal. Dice Guerra:

$30 \quad$ Joel Gn (2011). "Queer simulation: The practice, performance and pleasure of cosplay". "Cosplay or costume play is a performance art in which the individual imitates a character from a film, comic book, or video game. Cosplayers often have an ambiguous appearance which may seem to challenge the essential differences of the gendered body, yet it should be noted that the physical imitation of a fictitious character or artificial body does not directly translate into an expression of the individual's gender identity. [...] the cosplay performance denotes a consumption of the image which provokes the need for an alternative reading on deviance. [La representación del cosplayer opera como] as materializations of sexual difference, by demonstrating how the cosplay act becomes an unstable, yet pleasurable simulation of the visual image". 
Es en este cronotopo de figuras periféricas donde emerge el homosexual como leitmotiv que desgarra tanto el imaginario intelectual que revierte al dilema ontológico, como el repertorio estereotípico. La loca, en la ambigüedad subversiva de un Él/ Ella, es el desecho de la cultura y el patrimonio nacional, una cuña del Deseo que marca surcos en la piel aparentemente tersa y próspera del Chile Actual, desafiando roles genéricos y esfumando fronteras (Guerra 87).

Finalmente, tenemos tres elementos constitutivos de la originalidad de la obra cronística de Lemebel: escritura paródica y neobarroca; afirmación de la identidad gay a partir de las relaciones y funciones que el Yo establece con los otros (relación de provocación y poder) y creación de una cartografía alternativa que rediseña los espacios transitados. Así lo resume Lucía Guerra:

El deambular del Yo desecante en las crónicas de Pedro Lemebel es el correlato objetivo de otro acaecer a nivel de una subjetividad que se encuentra en un constante devenir. Y, en los escenarios distópicos de la ciudad anal que corre a la par de la urbe oficializada, el homosexual de los sectores populares se erige en La esquina es mi corazón como la figura epítome de la transgresión y la discriminación, en el símbolo que crudamente devela el fundamento oculto del sistema neoliberal: la desigualdad, la injusticia y la exclusión discriminatoria.

\section{CONCLUSIONES}

El recorrido analítico a través del corpus escogido permite concluir que la representación de la ciudad y lo urbano es una motivación constante para la literatura latinoamericana actual. Salvo en el caso de Rimbaud, los ejemplos se asocian a la poesía y narrativa chilenas contemporáneas. En la misma línea que Rimbaud, el imaginario urbano se despliega en un conjunto de metáforas visionarias, corpóreas, sinestésicas. Desde las asociaciones simbolistas, basadas en el montaje visual, hasta la barroca estructura de frase de Pedro Lemebel, pasando por la mezcla de oralidad y norma culta de Enrique Lihn, surge una retórica urbana de la ficción poética, alimentada por los lugares comunes de la cultura de masas, el legado de la tradición literaria de Occidente y los hallazgos estilísticos de cada narrador o poeta. La parodia de tópicos de la tradición caracteriza a la ciudad con ingredientes nostálgicos, amenazantes o alienantes para la sociedad y el individuo. Se 
invoca, en su lugar, una mítica ciudad premoderna, asociada con la infancia o adolescencia del sujeto. Si bien predomina el género poético, aparecen la escritura novelesca y la crónica como discursos revitalizados por la lectura crítica que los creadores hacen de la modernidad. Junto con la transformación del hablante poético, narrador o testigo, en protagonista de una trama cívica inestable o catastrófica, surge la apelación a un lector implícito que es invitado a ser cómplice de las experiencias de enunciación y escritura sobre la ciudad. Finalmente, los recursos estilísticos, las intertextualidades, la enciclopedia cultural que estos textos emplean, representan un reto para la hermenéutica del artefacto literario que se agrega a la multiplicidad de objetos culturales que conviven en la ciudad.

Según Federico Schopf, la antipoesía está estrechamente vinculada a los paisajes y voces de la metrópolis. Su razón de ser radica en las posibilidades de producción y transmisión de discursos irónicos y paródicos en circuitos cívicos y académicos. La oposición campo/ ciudad, en el análisis de Skármeta, adquiere nuevos significados a la luz de una crítica de la autenticidad y enajenación que provoca la vida mental en las grandes urbes. Favi y Bianchi coinciden en que, a la dimensión de la representación se deben agregar la pragmática del lector/ habitante y los actos performativos que los propios artefactos poéticos inauguran. Siguiendo a Epple y Lucía Guerra, entendemos que, en una etapa avanzada de la modernización latinoamericana, se someten a revisión las utopías de desarrollo en los contextos de dictadura y recuperación de la democracia. Surge, entonces, la necesidad de levantar un testimonio de las ciudades arrasadas por el progreso, y de las memorias obliteradas por los pactos de consenso. La irrupción de la escritura desde los márgenes (Lemebel), que toma por asalto los discursos públicos, inaugura un ciclo en que las enunciaciones de las otredades genéricas, políticas y sociales remecen los cánones literarios y obligan a los estudios académicos a renovar sus herramientas de análisis. Siempre sin olvidar, como nos lo recuerda el análisis de Carlos Morand, que la obra poética es un objeto autónomo en su ontología ficcional, abierto a múltiples aproximaciones hermenéuticas y contextualizaciones culturales.

En un período de treinta años, en el que caben fácilmente dos generaciones de autores, lectores e investigadores, la aproximación a la representación de la ciudad se ha hecho cada vez más compleja. Se han abierto las significaciones del texto al contexto que lo produce, imbricando la experiencia comprometida del testimonio y del género sexual con la edificación, a ratos, precaria, de un Yo habitante y lector competente de la ciudad. Y, lo más importante, surge la 
convicción de que habitante y lector también pueden ser gestores de actos de habla, actuaciones políticas y performances estéticas que, a su vez, impacten en el habitar urbano concreto y real. En esto consiste, creo, el legado de treinta años de estudios literarios en la Revista Chilena de Literatura de nuestra Universidad de Chile.

\section{BIBLIOGRAFÍA}

Berman, Marshall. Todo lo sólido se desvanece en el aire. México: Siglo XXI, 1982.

Bianchi, Soledad. "La imagen de la ciudad en la poesía chilena reciente". Revista Chilena de Literatura 30 (1987): 171-187.

"Paisajes (ciudad presente/ ciudad distante)". Revista Chilena de Literatura 54 (1999): 147-156.

Campra, Rosalba. "La ciudad y sus dobles". Marche Romane 43 (1993): 55-73.

Carpentier, Alejo, El reino de este mundo. Caracas: Monte Ávila, 1996 [1949].

Epple, Juan Armando. "De Santa a Mariana: la ciudad de México como utopía traicionada". Revista Chilena de Literatura 54 (1999): 31-42.

Favi, Gloria. "Enrique Lihn, cronista de ciudad". Revista Chilena de Literatura 43 (1993): 131-136.

"Las acciones de habla en un texto de Enrique Lihn: El Paseo Ahumada". Revista Chilena de Literatura 40 (1992): 91-96.

Foxley, Carmen. Enrique Lihn, escritura excéntrica y Modernidad. Santiago de Chile: Universitaria, 1995.

García Villavicencio, Jeannette. "Revista Chilena de Literatura: índice de autores, № 1 1970№60, 2002". Revista Chilena de Literatura 61 (2002): 221-270.

Guerra Cunningham, Lucía. "Ciudad neoliberal y los devenires de la homosexualidad en las crónicas urbanas de Pedro Lemebel". Revista Chilena de Literatura 56 (2000): 71-92.

Harvey, William. Exercitatio Anatomica De Motu Cordis et Sanguinis In Animalibus. Francofurti: Guilielmi Fitzeri, 1628.

Heidegger, Martin. "Bauen, Wohnen, Denken”. Vorträge und Aufsätze. Pfullingen: G. Neske, 1954 [1951].

Joel Gn. "Queer simulation: The practice, performance and pleasure of cosplay". Continuum, Journal of Media and Cultural Studies, Vol. 25, Issue 4 (2011): 583-593.

Lefebvre, Henri. El derecho a la ciudad. Barcelona: Ediciones Península, 1969.

La revolución urbana. Madrid: Alianza, 1970.

Low, Setha M. "The Anthropology of Cities: Imagining and Theorizing the City". Annual Review of Anthropology 25 (1996): 383-409.

Millán, Gonzalo. Vida. Ottawa: Cordillera, 1984. 
Morand, Carlos. "Las ciudades en Les Illuminations de Jean-Arthur Rimbaud". Revista Chilena de Literatura 8 (1977): 109-119.

Mumford, Lewis. The Culture of Cities. New York: Harcourt, Brace \& World, 1938.

Piglia, Ricardo. El último lector. Buenos Aires: Anagrama, 2005.

Ramos, Julio. Desencuentros de la Modernidad en América Latina. México: Fondo de Cultura Económica, primera reimpresión, 2003 [1989].

Schopf, Federico. "La ciudad en la poesía chilena: Neruda, Parra, Lihn". Revista Chilena de Literatura 26 (1985): 37-53.

Searle, John. Speech Acts: An essay in the Philosophy of Language. London: Cambridge University Press, 1969.

Simmel, Georg. "Las grandes urbes y la vida del espíritu”. Discusión 2 (1978): 11-24 [1903].

Skármeta, Antonio. "El motivo de oposición entre aldea y ciudad en dos dramas chilenos". Revista Chilena de Literatura 1 (1970): 31-41. 